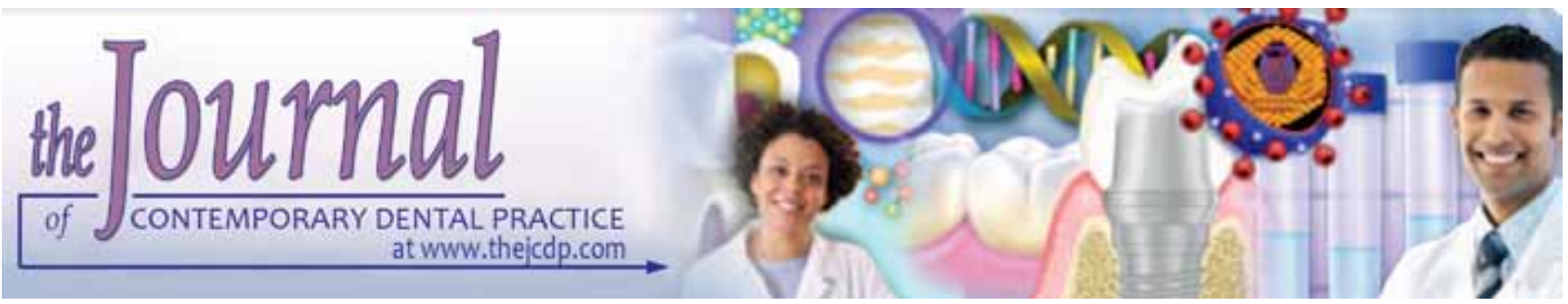

\title{
Sealing Ability of Four Calcium Containing Cements used for Repairing Furcal Perforations in Primary Molars: An in vitro study
}

${ }^{1}$ Heba M El-Khodary, ${ }^{2}$ Deema J Farsi, ${ }^{3}$ Najat M Farsi, ${ }^{4}$ Ahmed Z Zidan

\section{ABSTRACT}

Aim: The aim of this study was to compare the sealing ability of mineral trioxide aggregate (MTA), Portland cement (PC), Biodentine $^{\mathrm{TM}}$ and Tech biosealer in repairing furcal perforations in primary molars using the fluid-filtration technique.

Materials and methods: Fifty freshly extracted maxillary second primary molars were sectioned horizontally at the furcation region to create dentin disks of $1.5 \mathrm{~mm}(+0.1 \mathrm{~mm})$ thickness. Five disks were not perforated and served as negative controls. In the remaining 45 disks, furcation perforations were prepared. Five disks did not receive furcation repair and served as positive controls. The remaining 40 disks were then randomly divided into four equal groups (10 disks in each group). Perforations were repaired with: MTA, PC, Biodentine ${ }^{\mathrm{TM}}$ or Tech Biosealer. The sealing ability of the tested materials was evaluated by measuring microleakage for each disk after four different storage periods: 24-hour, 1-month, 6-month and 1-year storage using fluid-filtration. Comparisons between the four materials and the four time periods were done using the two-way analysis of variance and the Scheffe multiple comparisons test.

Results: There was no significant difference between the mean microleakage values obtained in the four tested materials after

${ }^{1}$ Department of Pediatric Dentistry, Faculty of Dentistry, King Abdulaziz University, Jeddah, Saudi Arabia; Department of Pedodontics, Faculty of Dental Medicine (Girls' Branch), Al Azhar University, Cairo, Egypt

2,3 Department of Pediatric Dentistry, Faculty of Dentistry, King Abdulaziz University, Jeddah, Saudi Arabia

${ }^{4}$ Department of Biomaterials, Faculty of Dentistry, October University for Modern Sciences and Arts, Egypt; Department of Restorative Dentistry, Biomaterials Division, Faculty of Dentistry, Umm AIQura University, Saudi Arabia

Corresponding Author: Deema J Farsi, Assistant Professor Department of Pediatric Dentistry, Faculty of Dentistry, King Abdulaziz University, Jeddah, Saudi Arabia, Phone: +966-555681880, e-mail: deema.farsi@gmail.com
24 hours, 1, 6 month and 1 year. However, microleakage values for each individual material were significantly higher at 24 hours than at the other time intervals.

Conclusion: Mineral trioxide aggregate, $\mathrm{PC}$, Biodentine ${ }^{\mathrm{TM}}$ and Tech biosealer showed similar capabilities in sealing the furcal perforations of the primary molars, where the sealing ability improved over time for each individual material.

Keywords: Biodentine ${ }^{\mathrm{TM}}$, Fluid-filtration technique, Furcal perforation, Microleakage, MTA, Portland cement, Primary molars, Tech biosealer.

How to cite this article: El-Khodary HM, Farsi DJ, Farsi NM, Zidan AZ. Sealing Ability of Four Calcium Containing Cements used for Repairing Furcal Perforations in Primary Molars: An in vitro study. J Contemp Dent Pract 2015;16(9):733-739.

Source of support: Nil

Conflict of interest: None

\section{INTRODUCTION}

Preservation of primary teeth before eruption of their permanent successors is desirable as they help maintain the integrity of natural dentition, which is essential for full function and esthetics. ${ }^{1}$ Conservative pulp therapy for primary teeth aims to maintain pulp vitality and promote the retention of these teeth until naturally timed exfoliation. Pulpotomy, a form of vital pulp therapy, is usually performed on carious or traumatic exposures in primary teeth with normal pulp or primary teeth with reversible pulpitis. ${ }^{2}$

Despite the relative ease in performing pulpotomies, iatrogenic problems can occur by undergraduate students with limited experience especially when handling young children. Sometimes they accidently perforate the floor of the pulp chamber during establishing access opening. Perforations in the crown, floor of the pulp chamber (furcation perforations) or the coronal third of the roots 
are considered as undesirable accidents that affects the prognosis of the suggested treatment. Immediate sealing of perforations with a suitable repair material can increase the chances for tooth preservation. ${ }^{3}$

Several materials have been proposed for sealing of perforations. However, the diverse outcomes have demonstrated that no single ideal sealing material has been identified. ${ }^{4}$ Biocompatible materials with a short setting time, good sealing ability, bone formation induction, easy manipulation and reasonable cost should be selected. ${ }^{5}$ These materials include zinc oxide eugenol cements (IRM and Super-EBA), glass ionomer cements, resin composites, resin modified glass ionomer (RMGI), and calcium silicate based cements.

Mineral trioxide aggregate (MTA) biomaterial was introduced to endodontics by Torabinejad in 1993. It can induce cementum deposition when used to seal lateral and furcal perforations. ${ }^{3,6}$ It preserves normal pulpal architecture and induces thick dentin bridges with little or no signs of inflammation. ${ }^{7,8}$ It is also implemented successfully as a vital pulp capping agent, apical plug in one visit apexification and as a root end filling material due to its low toxicity, antibacterial effect and its ability to induce hard tissue formation adjacent to pulp. ${ }^{2,3,9}$

The Portland cements (PC), designed for medicine and dentistry, also called hydraulic silicate cements mainly contain tricalcium silicate $\left(3 \mathrm{CaO}-\mathrm{SiO}_{2} ; \mathrm{C}_{3} \mathrm{~S}\right)$ which is responsible for development of early strength. ${ }^{10}$ Due to its low cost, antimicrobial activity, similar biocompatible properties to MTA and low genotoxicity, PC is considered as a possible substitute for MTA in endodontic applications and repair of perforation. ${ }^{11-16}$ When being placed in contact with pulp tissue, MTA and PC provide the same tissue response for direct pulp capping and pulpotomy. ${ }^{12,15}$

Despite the good clinical qualities of these materials, long setting time, less compressive and flexural strength, lack of bonding to enamel and dentin and difficult handling properties are reported as drawbacks. New calcium silicate-based materials have recently been developed in an attempt to improve the drawbacks of MTA and PC. ${ }^{17-20}$ Among these materials are Biodentine ${ }^{\mathrm{TM}}$ and Tech Biosealer; Biodentine ${ }^{\mathrm{TM}}$ is a cement of the same class as MTA. It is a dentin substitute that can be used in contact with the pulp. Biologically, it has good sealing properties, biocompatibility and capability of inducing odontoblast differentiation and apposition of reparative dentin. ${ }^{21,22}$ Biodentine $^{\mathrm{TM}}$ has a wide range of applications including endodontic repair: root perforations, resorptive lesions, retrograde filling material in endodontic surgery and pulp capping. It is formulated using MTA based cement technology to improve some of the MTA properties related to physical qualities and handling. ${ }^{23,24}$ Tech Biosealer is another newly introduced calcium-containing material. According to manufactures it exhibits perfect biocompatibility with exposed pulp tissue, stimulates pulp stem cells and induces formation of secondary dentin in 3 to 4 weeks. ${ }^{25}$ It can be used for vital pulp therapy, perforation repair and root-end filling (www. isasan.com).$^{22}$ The aim of this study was to compare the sealing ability of MTA, Biodentine ${ }^{\mathrm{TM}}$ and Tech Biosealer in repairing furcal perforation in primary molars using the fluid-filtration technique.

\section{MATERIALS AND METHODS}

The study protocol was approved by the ethics committee at the Faculty of Dentistry at King Abdulaziz University (KAUFD). Freshly extracted maxillary second primary molars were selected for this study. This molar was specifically selected as it has the thickest dentin in the furcation area among all primary teeth. ${ }^{26}$ Only teeth with no furcation involvement nor considerable root resorption were included. Fifty molars that met the inclusion criteria were used. After extraction, the teeth were cleaned from any debris, washed under tap water and stored in phosphate buffer saline (PBS) at room temperature for no more than 1 month. This storage medium was used in particular as it best simulates the in vivo conditions, and thus improves the sealing ability of biomaterials. ${ }^{27}$

\section{Teeth Preparation}

All molars were amputated $2 \mathrm{~mm}$ below the furcation area using a tapered diamond stone (Dentsply Maillefer, Ballaigues, Switzerland). Complete de-roofing of the pulp chamber of each molar was done using a round bur \#2 (Dentsply Maillefer, Ballaigues, Switzerland) and the root canal orifices were located. ${ }^{28}$ The canal orifices and the apical end of each root were etched with $37 \%$ phosphoric acid gel (Ivoclar Vivadent, Liechtenstein) for 30 seconds and were thoroughly rinsed and dried. Then, the adhesive (Excite F, Ivoclar Vivadent, Liechtenstein) was applied in two consecutive coats followed by photo-polymerization for 10 seconds with light curing unit (LED: Bluephase ${ }^{\circledR} \mathrm{C} 5$ curing-light, $500 \mathrm{~mW} / \mathrm{cm}^{2}$, 430-490 nm, Ivoclar Vivadent AG FL-9494 Schaan/Liechtenstein, Austria).

Flowable resin composite (Tetric N-Flow, Ivoclar Vivadent, Liechtenstein) was used to fill the root canal orifices as well as the apical ends of the roots, then it was photo-polymerized for 40 seconds. $^{29}$

\section{Creation of Perforations}

Each molar was sectioned horizontally at the furcation region to create a dentin disk of $1.5 \mathrm{~mm}( \pm 0.1 \mathrm{~mm})$ 
thickness. This was done using 7/8 inch diamond disk mounted on a grinding machine and under water coolant. The thickness was adjusted using a caliper device (Graduated caliper, 0-25 mm, $0.01 \mathrm{~mm}$, Germany). Each disk was then covered completely from both sides with two successive layers of clear nail varnish in an attempt to increase the seal.

Five disks were not perforated and served as negative controls. Artificial furcation perforations were created in the center of 45 tested primary molar disks using round bur \#2 (Dentsply Maillefer, Ballaigues, Switzerland) in a low speed handpiece (Bienair, Switzerland). ${ }^{29}$

Five disks did not receive furcation repair and served as positive controls. The remaining 40 disks were then randomly divided into four equal groups (10 disks in each group): Group 1: Furcal perforations were repaired with MTA. Group 2: Furcal perforations were repaired with. Group 3: Furcal perforations were repaired with Biodentine $^{\mathrm{TM}}$. Group 4: Furcal perforations were repaired with Tech biosealar.

The chemical composition and the manufacturers of the materials used in this study (Table 1).

\section{Repair Procedures}

In group 1, perforations were repaired with ProRoot MTA. Mineral trioxide aggregate was mixed according to manufacturer's instructions, introduced into the perforation using a messing gun and compacted with a hand plugger against a flat clean glass slab. A cotton pellet, saturated with saline solution, was placed over the repair material and stored in a tightly closed container. The teeth were kept in $100 \%$ humidity for 24 hours at $37^{\circ} \mathrm{C} \pm 1$ in an incubator (Foc Incubator, Japan). This was essential for hardening and bioactivity of calciumcontaining cements. ${ }^{30,31}$

In group 2, perforations were repaired with PC. The powder was first refined by silk refiner and sterilized in hot air oven (Tau Steril, Fino Mornasto, Como, Italy) at $170^{\circ} \mathrm{C}$ for 1 hour. One gram of the powder was then mixed with $0.33 \mathrm{ml}$ sterile distilled water to produce a homogenous paste with a consistency similar to that of MTA. The procedure was then completed as in group 1.

In group 3, perforations were repaired with Biodenti$\mathrm{ne}^{\mathrm{TM}}$. Biodentine $\mathrm{T}^{\mathrm{TM}}$ capsule was gently tapped against a hard surface to diffuse the powder, five drops of the liquid from the single-dose dispenser were poured into the capsule. The capsule was mixed in a triturator (Degoetzen, Italy) for 30 seconds, then introduced into the perforation using a messing gun and delicately compacted with a root canal plugger. The procedure was then completed as in group 1.

In group 4, perforations were repaired with Tech Biosealar. The powder was mixed with the liquid to produce
Table 1: The chemical composition and the manufacturers of the materials used in this study

\begin{tabular}{|c|c|c|c|}
\hline Materials & Composition & Manufacturer & Lot \# \\
\hline ProRoot MTA & $\begin{array}{l}\text { Powder: } \\
\text { 'Dicalcium silicate' } \\
\text { 'Tricalcium aluminate' } \\
\text { 'Tetracalcium alumino- } \\
\text { ferrite' } \\
\text { Calcium sulfate } \\
\text { dihydrate } \\
\text { Bismuth oxide } \\
\text { Liquid: }\end{array}$ & $\begin{array}{l}\text { 'Angelus- } \\
\text { Londrina, } \\
\text { PR, Brazil' }\end{array}$ & 7854 \\
\hline $\begin{array}{l}\text { Grey } \\
\text { Portland } \\
\text { Cement }\end{array}$ & $\begin{array}{l}\text { Powder: } \\
\text { 'Tricalcium silicate' } \\
\text { 'Dicalcium silicate' } \\
\text { 'Tricalcium aluminate' } \\
\text { Tetracalcium alumino- } \\
\text { ferrite } \\
\text { Calcium sulfate } \\
\text { dihydrate } \\
\text { Liquid: }\end{array}$ & $\begin{array}{l}\text { 'Helwan } \\
\text { cement } \\
\text { company, } \\
\text { Egypt' }\end{array}$ & $\mathrm{CTH} 1 / 2$ \\
\hline Biodentine $^{\mathrm{TM}}$ & $\begin{array}{l}\text { Powder: } \\
\text { 'Tricalcium silicate' } \\
\text { 'Dicalcium silicate' } \\
\text { 'Calcium carbonate and } \\
\text { oxide' } \\
\text { Iron oxide } \\
\text { Zirconium oxide } \\
\text { Liquid: } \\
\text { Calcium chloride } \\
\text { Hydrosoluble polymer }\end{array}$ & $\begin{array}{l}\text { 'Septodont, } \\
\text { Saint Maur } \\
\text { des Fosse's, } \\
\text { France' }\end{array}$ & B02150 \\
\hline $\begin{array}{l}\text { Tech } \\
\text { Biosealer }\end{array}$ & $\begin{array}{l}\text { Powder: } \\
\text { 'Calcium sulfate } \\
\text { hemihydrate' } \\
\text { 'Calcium chloride' } \\
\text { 'Bismuth oxide' } \\
\text { Montmorillonite sodium } \\
\text { fluoride } \\
\text { Liquid: } \\
\text { Dulbecco's phosphate }\end{array}$ & $\begin{array}{l}\text { Isasan, } \\
\text { Rovello } \\
\text { Porro-Co, } \\
\text { Italy }\end{array}$ & E10047 \\
\hline
\end{tabular}

a homogenous paste according to manufacturer instructions and then procedure was completed as in group 1.

Sealing ability was assessed by measuring microleakage for each disk after four different storage periods; 24 hours, 1-month, 6-months and 1-year storage period.

\section{Microleakage Measurement}

A fluid filtration device was used to measure fluid penetration through the tested materials induced by hydrostatic pressure. This was done by following the progress of an air bubble travelling within a $25 \mu \mathrm{l}$ micropipette; the apparatus was constructed according to the device originally designed by Pashley and Galloway in 1985 with slight modification to fit the test. ${ }^{32}$ The apparatus was connected to an electric pump to provide controlled pressure $(160 \mathrm{~mm} \mathrm{Hg}) .^{33}$ The fluid filtration device included ten pairs of split Teflon chambers. The split chamber device consists of two parts, female and male parts which were attached to each other by screwing 
action. Pairs of identical ' $\mathrm{O}$ ' rubber rings that snugly fit within the female part were prepared to adapt the disks and seal the chamber. Equal lengths of rubber tubes were used to connect the female parts to the metallic mother rod of the filtration device from one side. Similarly, these rubber tubes connect the male parts of the device to graduated $25 \mu \mathrm{l}$ glass micropipettes from the other side. All the apparatus connections were immersed in PBS. Care was taken to fill all the inner parts of the assembly with PBS with minimal presence of air bubbles.

After mounting all the disks into their split chambers, a preapplied pressure was used to check for any leaks while ultratight fittings were used throughout the whole system. The preapplied pressure also forced the fluid into any voids present in the filling materials. If leaks were observed in the fittings during this pretest, sealing of these leaks was performed meticulously. Such measures helped to ensure that any subsequent fluid movement was due to leakage in the material itself and not because of flaws in the technique. An air bubble was created in each pipette, and its location was determined for every specimen and recorded. The adjusted hydrostatic pressure was applied, through the female part of the chamber, and the fluid was forced through the voids along the filling materials. The fluid flowed out from specimens through the male part displacing the air bubble in the glass micropipette. Measurements of fluid movement were made at 2-minute intervals for 8 minutes, which were then averaged. This procedure was performed after 24 hours, 1, 6 and 12 months. The volume of the fluid transport was measured by tracing the linear displacement of the air bubble on top of a millimeter scale. ${ }^{34-36}$ Knowing the volume and the length of the micropipette, the linear movement of the bubble was converted and expressed in $\mu \mathrm{l} / \mathrm{min}^{37}$

\section{STATISTICAL METHODS}

Data analysis was performed using Statistical package for social sciences (SPSS) version 17. Comparisons between the four materials and the four time periods were done using the two-way analysis of variance. Pairwise comparisons between the time periods were performed using the Scheffe multiple comparisons test. ${ }^{38}$ All p-values were two-sided. $\mathrm{p}$-values $<0.05$ were considered significant.

\section{RESULTS}

The mean linear movement was assessed as $\mu \mathrm{l} / \mathrm{min}$ for each group. There was no noticeable movement of the air bubble in the negative control disks, while the bubble moved too quickly to be recorded in the positive control groups. At 24 hours, the means were 0.59 ( \pm 0.17$), 0.61$ $( \pm 0.19), 0.54( \pm 0.12)$ and $0.56( \pm 0.17)$ for the MTA, PC, Biodentine $^{\mathrm{TM}}$ and Tech biosealer groups respectively. There was no significant difference between the mean microleakage values obtained by the four tested materials. Comparable readings between the four materials were observed at 1, 6 months and 1 year as well, without a significant difference between the different materials. However, there was a significant difference between the microleakage value obtained after 24 hours and those obtained after 1,6 months and 1 year for each individual material ( $p$-value < 0.001). The microleakage for each individual material was the highest at 24 hours, improved over the 1st month and remained relatively constant up to 1 year. The data was presented as means and standard deviation (SD) values in Table 2 and Graph 1.

\section{DISCUSSION}

Furcal perforations adversely affect the prognosis of pulpotomy-treated teeth. Management of these iatrogenic accidents can pose a significant clinical challenge, especially when they occur in primary teeth. Although

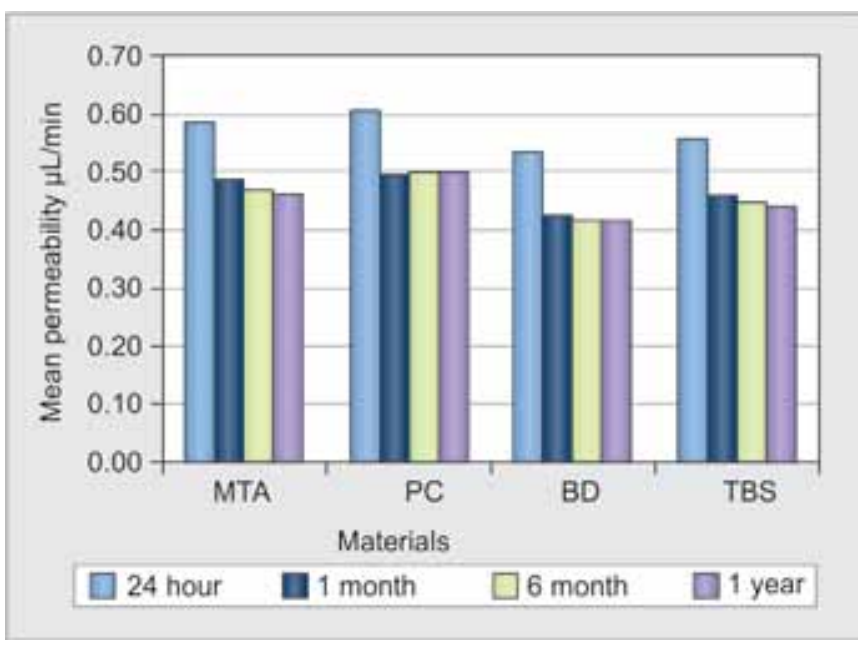

Graph 1: A histogram showing mean microleakage values and standard deviations of the four tested materials at different storage periods

Table 2: Mean microleakage values and standard deviations of the four tested materials in $(\mu \mathrm{l} / \mathrm{min})$ after different storage periods

\begin{tabular}{|c|c|c|c|c|c|c|c|c|c|}
\hline \multirow{2}{*}{$\begin{array}{l}\text { Groups } \\
\text { testing periods }\end{array}$} & \multicolumn{2}{|c|}{ MTA } & \multicolumn{2}{|c|}{$P C$} & \multicolumn{2}{|c|}{$\mathrm{Bio}^{T M}$} & \multicolumn{2}{|c|}{ TBS } & \multirow[b]{2}{*}{$p$-value } \\
\hline & Mean & $S D$ & Mean & $S D$ & Mean & $S D$ & Mean & $S D$ & \\
\hline 24 hours & 0.59 & 0.17 & 0.61 & 0.19 & 0.54 & 0.12 & 0.56 & 0.17 & $<0.001$ \\
\hline 1 Month & 0.49 & 0.09 & 0.50 & 0.13 & 0.43 & 0.14 & 0.47 & 0.14 & $<0.001$ \\
\hline 6 Months & 0.47 & 0.09 & 0.50 & 0.14 & 0.42 & 0.15 & 0.45 & 0.14 & $<0.001$ \\
\hline 1 Year & 0.46 & 0.07 & 0.50 & 0.12 & 0.42 & 0.15 & 0.44 & 0.15 & $<0.001$ \\
\hline
\end{tabular}


many materials have been studied in an attempt to find an ideal root end filling material, no single material has been identified yet. Many restorative materials have been used for repairing furcation perforation. Studies have shown that such materials have not been able to produce consistent results mostly due to leakage or lack of biocompatibility. ${ }^{39,40}$

Calcium silicate cements have gradually become the material of choice for the repair of all types of dentinal defects creating communication pathways between the root canal system and the periodontal ligament. With their proven biocompatibility and ability to induce calciumphosphate precipitation at the interface with the periodontal tissue, they play a major role in bone tissue repair. The high quality of the material-dentin interface, which improves over time, secures long-term clinical success and reduces the risk of marginal percolation.

Mineral trioxide aggregate's sealing ability as a furcal repair material was tested by earlier studies where MTA has shown less leakage than amalgam and Super EBA and has been proven to be less cytotoxic and neurotoxic than other repair materials. ${ }^{29,31,41}$ Though little amount of research published on PC, they have demonstrated comparable physical and biological properties as well as clinical outcomes to those of MTA, with the advantage of lower cost. ${ }^{12,42-44}$ Both MTA and PC have disadvantages as slow setting kinetics and complicated handling, which rendered these materials technique-sensitive and thus restricted their use to specialists. Although MTA has various promising properties, its handling characteristics and setting time is less than ideal. Though studies suggested that different additives or storage media can improve its properties yet further investigations are still needed as reported by Khedmat et al 2014 and Dorileo et al $2014 .^{22,45}$

In this study, the newly introduced calcium silicate cements, Biodentine ${ }^{\mathrm{TM}}$ and Tech Biosealer with modified powder composition, added setting accelerators and softeners and the new predosed capsule formulation were used and compared with MTA and PC to evaluate their sealing ability as less technique-sensitive and easier-touse as furcation repair materials.

Different leakage models have been used to access the ability of materials to seal furcation perforations including fluid filtration, dye penetration, dye extraction and bacterial-leakage models. ${ }^{29,43}$ The fluid filtration method was chosen in this study because it permits both qualitative and quantitative measurement of microleakage over longitudinal time periods without destruction of experimental specimens. ${ }^{31}$ This is important clinically because short-term and long-term performance can be measured. The quantitative data were provided by the movement of the air bubble through the micropipette (fluid flow), whereas the qualitative data were obtained by the percentage of the samples in which fluid flow was detected. Dye leakage studies measure the degree of leakage in one plane, making it impossible to evaluate the total amount of leakage. ${ }^{46}$ Some studies have reported fluid filtration model was more reproducible and sensitive than dye penetration. ${ }^{47,48}$ De-Deus et al in 2007 has reported that the fluid filtration method can detect any fault invisible on radiographs or in cross sections in addition to its capability of measuring a wide range of fluid flow rates with precision. ${ }^{31}$

The sealing ability of the four tested materials was evaluated after 24 hours, 1, 6 months and 1 year. The volume of fluid that penetrated past or through the perforated site was measured accurately. In this study, the data indicated that there was no significant difference between the microleakage mean values obtained by the four tested materials. This could be attributed to the fact that the testing materials had similar formulations and physical properties, thus having the same mechanism of action in promoting the healing process of the perforated site. The four tested materials release calcium hydroxide that interacts with phosphate containing fluid to produce calcium deficient apatite which is the initial step of a hard tissue barrier formation. This was supported by Tay and Pashley (2008) and Gandolfi et al (2011) who agreed that calcium silicate cements when mixed with water or other fluids produce insoluble cements due to the formation of appetite precipitates. $^{47,48}$

In our study, the tested microleakage of calcium silicate cements decreased significantly over the 1st month, and remained relatively constant thereafter. This is probably due to their hydrophilic nature and slight expansion occurring when they are cured in a moist environment. All calcium silicate based cements used in this study, showed comparable significant decrease in microleakage values after 1 month and were capable of maintaining the improved sealing ability for the 12-month study period. This may be attributed to the formation of crystals at the repair interface which reduce the solubility of the materials. This observation was similarly documented in a study by Carmona et al in 2009 who concluded that calcium silicate cements release some of their components, thus triggering the initial precipitation of calcium phosphates that act as precursor for the carbonated apatite. ${ }^{49}$ This was further supported by Galhotra et al in 2013 who reported that MTA, as a calcium silicate based cement, maintained minimal microleakage after 2 weeks due to the formation of the colloidal gel that solidified to a hard structure. ${ }^{50}$

Though no significant difference between the microleakage mean values obtained by the four tested materials 
in the current study, Biodentine ${ }^{\mathrm{TM}}$ with its high compressive strength and short setting time can be used as an appropriate substitute for MTA and PC in repairing furcal perforation. Studies reported that Biodentine ${ }^{\mathrm{TM}}$ exhibits thicker Ca- and Si-rich layer, similar gingival fibroblast reaction and acceptable biological effects compared to MTA. ${ }^{51,52}$ Tech Biosealer, as a calcium silicate bioactive material due to calcium ions release and apatite deposit formation, though showed comparable sealing abilities in the current study to both MTA and Biodentine ${ }^{\mathrm{TM}}$, it still exhibits delayed setting time compared with other MTA cements due to the presence of NF in its composition as reported by Prati $20133^{53}$ Further trials are still recommended to test the different properties of these newly introduced calcium silicate materials and to confidently implement these newly introduced cements into clinical applications.

\section{CONCLUSION}

Based on the results of this study, it can be concluded that:

- Mineral Trioxide Aggregate, PC, Biodentine ${ }^{\mathrm{TM}}$ and Tech Biosealer showed similar capabilities in sealing the furcal perforations of the primary molars.

- The sealing ability of each of the four tested materials improved over the 1st month, and was maintained thereafter.

\section{ACKNOWLEDGMENTS}

This project was funded by the Deanship of Scientific Research (DSR), King Abdulaziz University, Jeddah. The authors, therefore, acknowledge with thanks DSR techni$\mathrm{cal}$ and financial support. The authors are very grateful to Professor Inas El-Attar, Professor of Biostatistics, Department of Biostatistics and Cancer Epidemiology, National Cancer Institute, Cairo University, Egypt for the invaluable help in the statistical part of this paper.

\section{CLINICAL SIGNIFICANCE}

There is general consensus that tooth extraction is the treatment of choice for primary molars with perforations. Some materials have been proposed for sealing of perforations yet some drawbacks are reported. The current study encourages the use of new calcium silicate cements that have good sealing ability, biocompatibility and better physical and handling properties to MTA and $\mathrm{PC}$ as perforation repair biomaterial.

\section{REFERENCES}

1. Jeevani E, Jayaprakash T, Bolla N, Vemuri S, Sunil CR, Kalluru RS. Evaluation of sealing ability of MM-MTA, endosequence, and biodentine as furcation repair materials: UV spectrophotometric analysis. J Conserv Dent 2014 Jul; 17(4):340-343.
2. Ng FK and Messer LB. Mineral trioxide aggregate as a pulpotomy medicament: An evidence-based assessment. Europian Arch Pediat Dentist 2008;9(2):58-73.

3. Haghgoo R, Niyakan M, Nazari Moghaddam K, Asgary S, Mostafaloo N. An in vitro comparison of furcal perforation repaired with pro-root MTA and new endodontic cement in primary molar teeth-a microleakage study. J Dent Shiraz 2014 Mar; 15(1):28-32.

4. Ruddle JG. Nonsurgical endodontic retreatment. In: Cohn S, Burns RC, editoris. Pathways of the pulp. 8th ed. St Louis: Mosby. Inc, 2002:919.

5. Fuss Z, Abramovitz I, Metzger Z. Sealing furcation perforations with silver glass Ionomer cement, an in vitro evaluation. J Endodont 2000;26:466-468.

6. Haghgoo R, Arfa S, Asgary S. Micro leakage of CEM cement and ProRoot MTA as furcal perforation repair materials in primary teeth. Iran Endod J 2013;8(4):187-190.

7. Aeinehchi M, Eslami B, Ghanbariha M, Saffar AS. Mineral trioxide aggregate (MTA) and calcium hydroxide as pulp capping agents in human teeth: a preliminary report. Int Endodont J 2002;36:225-231.

8. Agamy HA, Bakry NS, Mounir MMF, Avery DR. Comparison of mineral trioxide aggregate and formocresol as pulp capping agents in pulpotomized primary teeth. Pediat Dentist 2004;26:302-309.

9. Oliveira MG, Xavier CB, Demarco FF, Pinheiro AL, Costa AT, Pozza DH. Comparative chemical study of MTA and Portland cements. Braz Dent J 2007;18(1):3-7.

10. Darvell BW, Wu RC. MTA - a hydraulic silicate cement: review update and setting reaction. Dent Materials 2011;27(5):pp. 407-422.

11. Zeferino EG, Bueno CE, Oyama LM, Ribeiro DA. Ex vivo assessment of genotoxicity and cytotoxicity in murine fibroblasts exposed to white MTA or white Portland cement with 15\% bismuth oxide. Int Endod J 2010 Oct; 43(10):843-848.

12. Menezes R, Bramante CM, Letra A, Carvalho VGG, Garcia RB. Histologic evaluation of pulpotomies in dog using two types of mineral trioxide aggregate and white Portland cements as wound dressings. Oral Surg Oral Med Oral Pathol Oral Radiol Endodont 2004;98:376-399.

13. De-Deus G,Coutinho-Filho T. The use of white Portland cement as an apical plug in a tooth with a necrotic pulp and wideopen apex: a case report. Int Endod J 2007 Aug; 40(8):653-660.

14. Conti TR, Sakai VT, Fornetti AP, Moretti AB, Oliveira TM, Lourenço Neto N, Machado MA, Abdo RC. Pulpotomies with Portland cement in human primary molars. J Appl Oral Sci 2009 Jan-Feb;17(1):66-69.

15. Sakai VT, Moretti AB, Oliveira TM, Fornetti AP, Santos CF, Machado MA, Abdo RC. Pulpotomy of human primary molars with MTA and Portland cement: a randomised controlled trial. Br Dent J 2009 Aug 8;207(3):128-129.

16. Borges $\mathrm{AH}$, Bandeca MC, Tonetto MR, Faitaroni LA, Carvalho ER, Guerreiro-Tanomaru JM, Tanomaru Filho M. Portland cement use in dental root perforations: a long term follow-up. Case Rep Dent 2014.

17. Asgary S, Shahabi S, Jafarzadeh T, Amini S, Kheirieh S. The properties of a new endodontic material. J Endodont 2008; 34:990-993.

18. Camilleri J. Modification of mineral trioxide aggregate. Physical and mechanical properties. Int Endodont J 2008;41: 843-849.

19. Gandolfi MG, Pagani S, Perut F, Ciapetti G, Baldini N, Mongiorgi R, Prati C. Innovative silicate-based cements for 
endodontics: a study of osteoblast-like cell response. J Biomed Materials Res A 2008;87:477-486.

20. Dammaschke T, Gerth HUV, Zü chner H, Schafer E. Chemical and physical surface and bulk material characterization of white ProRoot MTA and two Portland cements. Dent Materials 2005;21:731-738.

21. Grech L, Mallia B, Camilleri J. Investigation of the physical properties of tricalcium silicate cement-based root-end filling materials. Dent Mater 2013 Feb;29(2):e20-28.

22. Khedmat S, Dehghan S, Hadjati J, Masoumi F, Nekoofar MH, Dummer PM. In vitro cytotoxicity of four calcium silicate-based endodontic cements on human monocytes, a colorimetric MTT assay. Restor Dent Endod 2014 Aug;39(3):149-154.

23. Biodentine-available at: www.universaldental.com.pk/ documents/Focus-biodentine_cs_1-pdf.

24. Malkondu Ö, Karapinar Kazandağ M, Kazazoğlu E. A review on biodentine, a contemporary dentine replacement and repair material. Biomed Res Int 2014 (2014), article ID 160951, p. 10. Available at: http://dx.doi.org/10.1155/2014/160951

25. Tech Biosealer-Isasan, Available at: www.isasan.com/ Prodotti/Tech_Biosealer.aspx.

26. Masthan KMK: Textbook of Human oral embryology, anatomy, physiology, histology and tooth morphology. 1st Ed. 2010; Jaypee Medical Publishers: New Delhi. p 185-197.

27. Parirokh M, Askarifard S, Mansouri S, Haghdoost AA, Raoof M, Torabinejad M. Effect of phosphate buffer saline on coronal leakage of mineral trioxide aggregate. J Oral Sci 2009 Jun;51(2):187-191.

28. Ahangari Z, Karami M. Evaluation of the sealing ability of amalgam, MTA, Portland cement and Coltozol in the repair of furcal perforations. Iran Endodont J 2006;1(2):60-64.

29. Hamad HA, Tordik PA, McClanahan SB. Furcation perforation repair comparing gray and white MTA: a dye extraction study. J Endodont 2006;32:337-340.

30. Nawareg MA. The effect of different surface treatments on dentin and adhesive permeability. PhD. Thesis, Cairo University, Faculty Oral and Dent Medi 2007; p 69.

31. De-Deus G, Reis C, Brandão C, Fidel S, Fidel RA. The ability of Portland cement, MTA, and MTA Bio to prevent throughand-through fluid movement in repaired furcal perforations. J Endodont 2007;33(11):1374-1377.

32. Pashley DH, Galloway SE. The effects of oxalate treatment on the smear layer of ground surfaces of human dentin. Arch Oral Biol 1985;30:731-737.

33. Cobankara FK, Orucoglu H, Sengun A, Belli S. The quantitative evaluation of apical sealing of four endodontic sealers. J Endodont 2006;32:66-68.

34. Vaysman T, Rajan N, Thompson VP. Effect of bur cutting patterns and dentin bonding agents on dentin permeability in a fluid flow model. Operat Dentist 2003;28:522-528.

35. Puapichartdumrong P, Ikeda $\mathrm{H}$, Suda $\mathrm{H}$. Outward fluid flow reduces inward diffusion of bacterial lipopolysaccharide across intact and demineralized dentin. Arch Oral Biol 2005;50:707-713.

36. Elgalaid TO, Youngson CC, Mc Hugh S, Hall AF, Creanor SL, Foye RH. In vitro dentin permeability: The relative effect of a dentine bonding agent on crown preparations. J Dentist 2004;32:413-421.

37. Vasiliadis l, Kodonas K, Economides N, Gogos C, Stavrianos C. Short and long-term sealing ability of Gutta flow and $\mathrm{AH}$ plus using an ex vivo fluid transport model. Int Endod J 2010;43:377-381.
38. Dawson B, Trapp GT. Basic and clinical biostatistics. 3rd ed. Lange medical book, Appleton and Lange, Norwalk, Connecticut 2001.

39. De-Deus G, Petruccelli E, Gurgel-Filho E, Coutinho-Fihlo T. Mineral trioxide aggregate versus Portland cement as repair cement material for furcal perforations: a laboratory study using a polymicrobial leakage model. Int Endodont J 2006;39:293-298.

40. Oliveira TM, Sakai VT, Silva TC, Santos CF, Machado MA, Abdo RC. Repair of furcal perforation treated with mineral trioxide aggregate in a primary molar tooth: 20-month followup. J Dentist Children 2008 May-Aug;75(2):188-191.

41. Asrari M, Lobner D. In vitro neurotoxic evaluation of rootend-filling materials. J Endodont 2003 Nov;29(11):743-746.

42. Min KS, Kim HI, Park HJ, Pi SH, Hong CU, Kim EC. Human pulp cells response to Portland cement in vitro. J Endodont 2007;33:163-166.

43. El-Tawil SB, El-Dokky NA, Abd El-Hamid D. Sealing ability of MTA versus Portland cement in the repair of furcal perforations of primary molars: A dye extraction leakage model. J Am Sci 2011;7(12):1037-1043. ISSN: 1545-1003. Available at: http://www.americanscience.org.

44. Chakraborty A. Will Portland cement be a cheaper alternative to mineral trioxide aggregate in clinical use?: A comprehensive review of literature. Int J Contemp Dent Med Rev (2015), article ID 110215, p. 7.

45. Dorileo MC, Pedro FL, Bandeca MC, Guedes OA, Villa RD, Borges AH. Comparative analysis of physicochemical properties of root perforation sealer materials. Restor Dent Endod 2014 Aug;39(3):201-209.

46. Shahi S, Rahimi S, Hasan M, Shiezadeh V, Abdolrahimi M. Sealing ability of mineral trioxide aggregate and Portland cement for furcal perforation repair: a protein leakage study. J Oral Sci 2009 Dec;51(4):601.

47. Tay FR, Pashley DH. Guided tissue remineralisation of partially demineralized human dentin. Biomaterials 2008 Mar;29(8):1127-1137.

48. Gandolfi MG, Taddei P, Siboni F, Modena E, De Stefano ED, Prati C. Biomimetic remineralization of human dentin using promising innovative calcium-silicate hybrid 'smart' materials. Dent Materials 2011 Nov;27(11):1055-1069.

49. Reyes-Carmona JF, Felippe MS, Felippe WT. Biomineralization ability and interaction of mineral trioxide aggregate and white portland cement with dentin in a phosphate-containing fluid. J Endodont 2009 May;35(5):731-736.

50. Galhotra V, Sofat A, Pandit IK, Gambhir RS, Srivastava N, Gugnani N. Comparative evaluation of microleakage of various retrograde filling materials: An in vitro study. J Nat Sci Bio Med 2013 Jul;4(2):403-408.

51. Han L1, Okiji T. Uptake of calcium and silicon released from calcium silicate-based endodontic materials into root canal dentine. Int Endod J 2011 Dec;44(12):1081-1087.

52. Zhou HM, Shen Y, Wang ZJ, Li L, Zheng YF, Häkkinen L, Haapasalo M. In vitro cytotoxicity evaluation of a novel root repair material. J Endod 2013 Apr;39(4):478-483.

53. Prati C, SiboniF, Polimeni A, Bossu M, Gandolfi MG. Use of calcium-containing endodontic sealers as apical barrier in fluid-contaminated wide-open apices. J Appl Biomater Funct Mater 2014 Dec 30;12(3):263-270. 